\title{
KOMUNIKASI PROMOSI BERSAMA DALAM MENINGKATKAN PENJUALAN PRODUK MASYARAKAT DESA DI KECAMATAN WARINGIN KURUNG
}

\author{
Restu Wahyuni, Rachmi Yulianti \\ Fakultas Ilmu Sosial dan Ilmu Politik Universitas Serang Raya \\ rst_wahyuni@yahoo.com,rachmi_yulianti@yahoo.com
}

\begin{abstract}
This study try to apply the promotion of communications collectively on the products of the village community with model pamphlet commerce and analyze the level of sales before and after promotion with model pamphlet commerce is applied. The results of this study are expected to minimally be able to overcome the impasse of marketing of village products that are less widespread and often trapped by the realtor marketing system. This research method using research development approach $(R \& D)$ of data in a limited, the research shows that the hypothesis testing on the application of pamphlet model commerce product of the village community as a joint promotion communication conducted in the sub-district waringinkurung generated thitung of -2.463 , which then the value is compared with the value of t table with degrees of freedom $(d k)=n 1+n 27$ $+7=14-2=12$. and the error rate of 5\%, then t table (0.05) (12) $=-2.178$ and in accordance with the test criteria that have been determined the results of the comparative hypothesis post test) on the implementation of the trade pamphlet $t$ is less than $t$ table $(-2,463<-2,178)$ so that the meaning is there is a significant difference in the effectiveness of product sales performance of villagers in Waringin Kurung subdistrict before and after the application of commercial pamphlet model as a promotion communication with him .
\end{abstract}

\section{Keyword: Commercial pamphlet implementation and Sales level}

\begin{abstract}
ABSTRAK
Penelitian ini bertujuan untuk mencoba menerapkan komunikasi promosi secara bersama pada produk masyarakat desa dengan model pamflet niaga dan menganalisis tingkat penjualannya sebelum dan setelah promosi dengan model pamflet niaga tersebut diterapkan. Hasil penelitian ini diharapkan minimalnya dapat mengatasi kebuntuan pemasaran produk desa yang kurang luas dan sering terjebak oleh sistem makelar pemasaran. Metode penelitian ini menggunakan pendekatan penelitian pengembangan (research and development). Dan berdasarkan hasil pengamatan serta analisis data secara terbatas, penelitian menunjukan bahwa pengujian hipotesis atas penerapan model pamflet niaga produk masyarakat desa sebagai komunikasi promosi bersama yang dilakukan di kecamatan waringinkurung dihasilkan nilai $\mathrm{t}$ hitung sebesar 2.463, yang selanjutnya nilai tersebut dibandingkan dengan nilai t tabelnya dengan derajat kebebasan $(\mathrm{dk})=\mathrm{n}_{1}+\mathrm{n}_{2} 7+7=14-2=12$. dan taraf kesalahan sebesar 5\%, maka t tabel $_{(0.05)(12)}=2,178$ dan sesuai dengan kriteria uji yang telah ditentukan hasil hipotesis komparatif (pre test dan post test) atas penerapan pamflet niaga tersebut $\mathrm{t}$ hitung lebih kecil dari t tabel $(-2,463<-2,178)$ sehingga maknanya adalah terdapat
\end{abstract}


perbedaan secara signifikan efektifitas kinerja penjualan produk masyarakat desa di kecamatan Waringin Kurung sebelum dan setelah penerapan model pamflet niaga sebagai komunikasi promosi bersamanya.

\section{Kata kunci : Penerapan Pamflet niaga dan Tingkat penjualan}

\section{PENDAHULUAN}

Salah satu kendala yang dihadapi produk masyarakat desa adalah bagaimana menjual produk dipasaran agar produk tersebut laku dan bisa lama bertahan di pasar, baik pasar yang terdapat di sekitar wilayahnya maupun pasar di luar wilayahnya dan bahkan bisa bersaing di daerah yang lebih jauh lagi, namun kenyataannya produk masyarakat desa hanya berjalan ditempat, di jual hanya pada tetangga sekitarnya, dan paling jauh produksinya di jual antar desa sehingga usahanya hanya sebatas pulang pokok saja, hal ini dikarenakan berbagai kendala, salah satunya adalah rendahnya kreatifitas masyarakat pada pengetahuan teknikteknik komunikasi promosi yang benar.

Masyarakat di Kecamatan Waringin Kurung pada umumnya memiliki kreatifitas yang baik dalam menciptakan produk dan sangat bervariatif, karena banyak sumber daya alam atau bahan baku yang tersedia desanya, namun upaya pemasaran produknya hanya menghasilkan keuntungan sebatas pulang pokok saja, rendahnya pengetahuan masyarakat tentang pengelolaan pemasaran sehingga ketidak tahuan pasar, mereka hanya mengira-ngira jumlah kapasitas produk yang akan diproduksinya setiap hari, yang selanjutnya di jual pada tetangga sekitarnya saja, dan paling jauh produksinya di jual antar desa, seperti, masyarakatnya kreatif dalam membudidayakan melon, namun melon tersebut hanya dijual di pinggiran jalan desa, kemudian hasil budidaya tersebut tidak terjual dengan baik dan menumpuk yang pada akhirnya melon tersebut busuk. Selanjutnya kerajinan anyaman oleh masyarakat, karena ketidaktahuan peluang pasar, mereka tidak berani memproduksi dalam jumlah yang banyak, mereka tidak percaya diri apakah nantinya produk yang dibuat akan laku jika diproduksi terlalu banyak.

Untuk itu perlu ada model pengelolaan komunikasi promosi yang kreatif yang perlu dilakukan oleh masyarakat desa di Kecamatan Waringin kurung, salah satunya dengan model promosi yang terkoordinir (bersama) diantara pemilik produk-produk kreatif masyarakat desa 
setempat, salah satunya yaitu dengan model pamflet niaga sebagai media komunikasi promosi produksinya

Memang model ini telah digunakan oleh minimarket-minimarket yang tersebar di wilayah Provinsi Banten, namun dalam pamflet niaga tersebut promosi produk hanya memuat produk-produk pabrikan yang sudah modern, dan tidak ada satupun produk unggulan desa yang ditampilkan secara berdampingan, pamflet hanya memuat tentang produk susu SGM, kopi torabika, minyak goreng Bimoli dan seterusnya dengan potongan harga yang mereka janjikan. Tanpa disadari kita pernah mendapatkan pamflet niaga tersebut dan membacanya bahkan terpengaruh olehnya untuk membeli salah satu produk yang di tampilkannya, dan tidak tanggung tanggung dengan janji-janji potongan harganya kita telah menginformasikan kepada keluarga kita, teman kita dan bahkan pada orang lain.

Masyarakat desa di Kecamatan Waringin Kurung pada umumnya memiliki banyak produk dan sangat bervariatif, mengapa tidak mencoba model komunikasi promosi produk tersebut (model pamflet niaga), tentunya diperlukan keahlian dan usaha yang serius untuk dapat melaksanakannya. Sampai saat ini distribusi pemasaran produk masyarakat desa masih dimanfaatkan oleh orangorang kota, untuk meraih keuntungan yang sebesar-besarnya dengan cara menjualkannya.

Pamflet niaga sering dimaknai sebagai katalog produk yang tujuannya memberikan informasi kepada pembaca mengenai produk-produk yang ada di dalam etalase toko si penjual dan tentu saja dalam pamflet niaga tersebut terdapat kata-kata persuasif untuk membeli produk dan kata-kata ajakan tersebut dapat berupa potongan harga atau penawaran-penawaran gratis.

Komunikasi promosi bersama dengan model pamflet niaga ini menjadi salah satu solusi masyarakat desa di Kecamatan Waringin Kurung sebagai tempat untuk memberikan informasi mengenai produk masyarakat desanya kepada calon pembeli, sehingga para konsumen dapat mengetahui kelebihan dan kekurangan produk tanpa harus datang langsung ke tempat usahanya. Selain itu pamflet niaga juga menjadi sarana bagi konsumen yang ingin melakukan pemesanan produk secara langsung karena dalam pamflet niaga tersebut tercantum lengkap alamat dimana sipenjual berada.

Berdasarkan pemaparan tersebut, maka rumusan masalah dalam penelitian ini adalah : 1) Bagaimana 
penerapan promosi produk masyarakat desa di Kecamatan Waringin Kurung ?; dan 2) Bagaimana tingkat penjualan produk masyarakat desa di Kecamatan Waringin Kurung sebelum dan setelah promosi bersama dengan model pamflet niaga di Kecamatan Waringin Kurung ?

Karena itu, tujuan penelitian ini adalah 1) untuk mengetahui penerapan promosi bersama produk masyarakat desa di Kecamatan Waringin Kurung; dan 2) untuk mengetahui tingkat penjualan produk masyarakat desa sebelum dan setelah penerapan komunikasi promosi bersama dengan model pamphlet niaga di Kecamatan Waringin Kurung

\section{KERANGKA PEMIKIRAN}

\section{Komunikasi Pemasaran}

Agar produk sampai ke konsumen, perusahaan harus mengomunikasikan produk tersebut kepada konsumen. Komunikasi ini bertujuan agar konsumen mengenal kegunaan, manfaat dan nilai lebih yang dimiliki suatu produk. Usaha perusahaan dalam mengomunikasikan produknya disebut komunikasi pemasaran. Menurut Sutisna (2011;267), komunikasi pemasaran merupakan usaha untuk menyampaikan pesan kepada publik terutama konsumen sasaran mengenai keberadaan produk di pasar. Sedangkan menurut Fandy Tjiptono (2012;219), komunikasi pemasaran adalah aktivitas yang berusaha menyebarkan informasi, mempengaruhi/membujuk, dan/atau mengingatkan pasar sasaran atas perusahaan dan produknya agar bersedia menerima, membeli, dan loyal pada produk yang ditawarkan perusahaan yang bersangkutan.

Schiffman dan Kanuk (2010;28), menambahkan, komunikasi tidak hanya menghubungkan konsumen dan produsen, tetapi juga menghubungkan konsumen dengan lingkungan sosialnya, yaitu komunikasi pemasaran bisa terjadi dalam dua jenis, yaitu komunikasi pemasaran yang berasal dari perusahaan dan yang berasal dari konsumen. Komunikasi pemasaran yang berasal dari perusahaan terjadi dalam bentuk promosi dan segala macam baurannya. Artinya perusahaan tersebut berusaha menginformasikan produk atau perusahaannya kepada masyarakat luas agar mereka mengenal dan kemudian membeli produk perusahaan tersebut. Sedangkan komunikasi pemasaran yang berasal dari masyarakat terjadi dalam bentuk respon yang merupakan akibat dari penggunaan produk suatu perusahaan, 
komunikasi jenis ini kemudian disebut word of mouth communication.

Dari keterangan di atas, word of mouth dapat terjadi secara alamiah ketika seorang konsumen merasa puas setelah mengonsumsi suatu produk dan menceritakan pengalamannya kepada orang lain, yang menyebabkan orang yang mendengarkan tersebut tertarik untuk mencoba dan melakukan pembelian sehingga menjadi konsumen baru produk tersebut. Dan konsumen baru tersebut menceritakan kembali kepada orang yang berbeda dan seterusnya. Seperti keterangan Wahyu Utomo, (2008) Satu hal perlu diingat para marketer: pergosipan antar konsumen tersebut memiliki kekuatan persuasi yang 1000 kali lebih hebat dari kekuatan salesman yang paling ampuh sekalipun. Seribu kali omongan salesman mengenai kehebatan sebuah produk tak ada artinya dibandingkan sekali omongan konsumen ke konsumen lain. Konsumen menjadi kekuatan yang maha dahsyat sebagai "salesman" yang jujur, orisinil, dan objektif dalam mempengaruhi konsumen lain. Inilah kehebatan pendekatan pemasaran masa depan, yang saya sebut "WOM marketing".

\section{Sistem Komunikasi Pemasaran.}

Untuk mencapai tujuan promosi, pemasar harus menguasai sistem komunikasi pemasaran agar komunikasi yang kita lakukan mencapai sasaran yang tepat. Dimana komunikasi pemasaran sering juga disebut dengan komunikasi promosi. Menurut Komaruddin Sastradipoera $(2003 ; 189)$, sistem komunikasi promosi adalah serangkaian komponen komunikasi yang mempunyai fungsi untuk mencapai tujuan promosi. Dalam arti yang lebih luas komunikasi dalam kegiatan promosi adalah setiap prosedur yang menyebabkan manajemen marketing dapat mempengaruhi sikap dan keputusan pelanggan atau calon pelanggan. Hal itu akan meliputi seluruh aspek perilaku manusia, tidak hanya meliputi pembicaraan oral dan naratif tulisan. Bila disederhanakan, komunikasi promosi itu memiliki empat unsur esensial yang meliputi sumber (source), saluran (channel), tujuan (destination), dan pesan (massage), pada tahapan pertama, sumber memilih pesan promosi khusus dari sejumlah pesan yang ada dan dirancang. Lebih jauh pesan itu disampaikan melalui saluran ketujuan.

\section{Pengertian Pamflet}

Pamflet umumnya digunakan sebagai media promosi bagi beberapa 
perusahaan untuk memperkenalkan produknya ke masyarakat. Banyak yang menggunakannya sebagai sarana promosi karena selain menghemat pengeluaran juga mudah dibuat, hanya memerlukan keterampilan berbahasa yang baik serta menarik.

Pamflet adalah sebuah tulisan yang berisi tentang suatu informasi yang terdiri dari tulisan termasuk gambar didalamnya yang umumnya dibuat pada selebaran dan tidak dijilid atau dibukukan. Pamflet diartikan juga tulisan yang dapat disertai dengan gambar atau tidak, tanpa penyampulan maupun penjilidan, yang dicantumkan pada selembar kertas di satu sisi atau kedua sisinya, lalu dilipat atau dipotong setengah, sepertiga, atau bahkan seperempatnya, sehingga terlihat lebih kecil (dapat juga disebut selebaran).

\section{Jenis-Jenis Pamflet}

Tujuan dari pamflet sendiri berbeda-beda antara satu dengan yang lainnya, tergantung pamflet jenis apa yang dibuat. Misalnya pamflet tentang promosi, maka memiliki tujuan untuk memberikan informasi mengenai produk, berbeda dengan pamflet tentang agama, biasanya berisi tentang ilmuilmu agama Pamflet terbagi menjadi empat kategori

\section{Pamflet Politik}

Informasi yang disampaikan biasanya berupa ajakan untuk memilih calon-calon baik itu kepala negara maupun kepala daerah.

\section{Pamflet Pendidikan}

Merupakan pamflet yang digunakan untuk kepentingan pendidikan, termasuk sosialisasi peraturan pemerintah dalam bidang pendidikan serta publikasi acara-acara pendidikan seperti seminar atau lomba cerdas cermat.

3. Pamflet Niaga

Pamflet niaga sering dimaknai sebagai katalog produk. Tujuannya memberikan informasi kepada pembaca mengenai produk-produk yang ada di dalam etalase toko si penjual. Tentu saja, terdapat kalimat-kalimat persuasif untuk membeli produk. Kalimat ajakan tersebut bisa berupa potongan harga atau penawaranpenawaran gratis.

\section{Pamflet Kegiatan}

Bertujuan sebagai alat publikasi kegiatan, bisa berupa seminar atau konser. Salah satu pamflet yang sering kita temui adalah pamflet seminar-seminar yang 
ditempel di dinding atau dibagikan melalui media sosial.

\section{Ciri-ciri pamflet}

Pamflet umumnya digunakan sebagai media promosi bagi beberapa perusahaan untuk memperkenalkan produknya ke masyarakat. Banyak yang menggunakannya sebagai sarana promosi karena selain menghemat pengeluaran juga mudah dibuat, hanya memerlukan keterampilan berbahasa yang baik serta menarik. Pamflet memiliki beberapa ciri yaitu sebagai berikut:

1. Menggunakan bahasa yang singkat, padat dan jelas

2. Bersifat persuasif, artinya berisi ajakan untuk membeli produk atau mentaati sesuatu ditulis dengan jelas supaya mudah dibaca

3. Hal-hal yang disampaikan biasanya mengenai hal-hal baru atau terupdate.

\section{Pengertian penjualan}

Penjualan merupakan salah satu fungsi pemasaran yang sangat penting dan menentukan bagi perusahaan dalam mencapai tujuan perusahaan yaitu memperoleh laba untuk menjaga kelangsungan hidup perusahaan. Sebenarnya pengertian penjualan sangat luas, beberapa para ahli mengemukakan tentang definisi penjualan antara lain :

Menurut Moekijat (2000:488), selling adalah melakukan penjualan adalah suatu kegiatan yang ditujukan untuk mencari pembeli, mempengaruhi dan memberikan petunjuk agar pembeli dapat menyesuaikan kebutuhannya dengan produk yang ditawarkan serta mengadakan perjanjian mengenai harga yang menguntungkan bagi kedua belah pihak. Sedangkan menurut Philip Kotler (2011 ; 8), penjualan adalah penjualan adalah proses sosial manajerial dimana individu dan kelompok mendapatkan apa yang mereka butuhkan dan inginkan, menciptakan, menawarkan, dan mempertukarkan produk yang bernilai dengan pihak lain. Menurut Kusnadi (2000;19), penjualan (sales) adalah sejumlah uang yang dibebankan kepada pembeli atas barang atau jasa yang dijual.

Faktor-faktor yang mempengaruhi Penjualan

Dalam praktek, kegiatan penjualan ini dipengaruhi oleh beberapa faktor yaitu :

1. Kondisi dan Kemampuan Pasar

Disini penjual harus dapat meyakinkan pembeli agar berhasil mencapai sasaran penjualan yang 
diharapkan untuk maksud tertentu, penjual harus memahami beberapa masalah penting yang sangat berkaitan yaitu

a. Jenis dan karakteristik barang yang ditawarkan

b. Harga Produk

c. Syarat penjualan seperti pembayaran, pengantaran, garansi, dan sebagainya.

2. Kondisi Pasar

Hal yang harus diperhatikan pada kondisi pasar antara lain:

a. Jenis pasarnya, apakah pasar konsumen, pasar industri, pasar pemerintah atau pasar Internasional

b. Kelompok pembeli dan segmen pasarnya

c. Daya beli

d. Frekuensi pembeliannya

e. Keinginan dan kebutuhan

3. Modal

Apakah modal kerja perusahaan mampu untuk mencapai target penjualan yang dianggarkan seperti untuk :

a. Kemampuan untuk membiayai penelitian pasar yang dilakukan

b. Kemampuan membiayai usahausaha untuk mencapai target penjualan c. Kemampuan membeli bahan mentah untuk dapat memenuhi target penjualan.

4. Kondisi Organisasi Perusahaan

Pada perusahaan besar, biasanya masalah penjualan ditangani oleh bagian penjualan. Lain halnya dengan perusahaan kecil, dimana masalah penjualan ditangani oleh orang yang juga melakukan fungsifungsi lain

\section{METODOLOGI PENELITIAN}

\section{Tipe Penelitian}

Metode penelitian yang digunakan adalah dengan menggunakan metode survei, yaitu sebuah desain penelitian yang memberikan uraian kuantitatif maupun numerik dari sejumlah pecahan populasi (sampel) melalui proses pengumpulan data dengan metode wawancara sebagai alat pengumpul datanya. Kemudian dilakukan pengujian hipotesis secara spesifik untuk mengetahui signifikansi peningkatan penjualan produk masyarakat desa sebelum dan setelah penerapan komunikasi promosi dengan model pamflet niaga tersebut.

Populasi dalam penelitian ini adalah pelaku usaha kecil yang berada di Kecamatan Waringin Kurung. Untuk mengetahui ada atau tidaknya korelasi antara penerapan pamflet niaga dengan 
tingkat penjualan di Waringin Kurung

dilakukan perhitungan korelasi

sederhana dengan rumus Product

Moment dari Pearson. Sedangkan untuk mengetahui pengaruh penerapan pamflet niaga dengan tingkat penjualan di Waringin Kurung digunakan koefisien regresi berganda. Dan untuk mengukur seberapa besar variabel independent $\left(\mathrm{x}_{1}\right)$ berperan terhadap variabel independent $\left(\mathrm{x}_{2}\right)$ maka digunakan perhitungan $\mathrm{t}$ test.

Adapun teknik analisis data yang digunakan untuk menguji hipotesis t-test. Teknik ini digunakan untuk menguji signifikansi hipotesis komparatif dua sampel yang berkorelasi, dengan menggunakan sampel idependent artinya menggunakan kelompok data dari orang yang sama,

1. Rumusan t-test yang digunakan untuk menguji hipotesis komparatif dua sampel yang berkorelasi adalah sebagai berikut

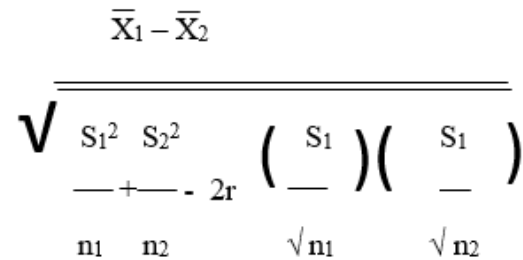

Dimana

X1 = Rata-rata Sampel satu

X2 = Rata-rata Sample satu

$\mathrm{S}_{1}=$ Simpangan baku sampel Satu
$\mathrm{S}_{2}=$ Simpangan baku sampel dua

$\mathrm{S}_{1}^{2}=$ Varian sampel Satu

$\mathrm{S}_{2}{ }^{2}=$ Varian sampel dua

$\mathrm{r}=$ Korelasi antar dua sampel

2. Sedangkan untuk mencari nilai korelasi dua sampel digunakan rumus

$$
\mathrm{r}=\frac{\mathrm{n} \sum \mathrm{X}_{1} \mathrm{X}_{2}-\sum \mathrm{X}_{1} \cdot \sum \mathrm{X}_{2}}{\sqrt{\left(\mathrm{n} \sum \mathrm{X}_{1}^{2}-\left(\sum \mathrm{X}_{1}\right)^{2}\right) \cdot\left(\mathrm{n} \sum \mathrm{X}_{2}^{2}-\left(\sum \mathrm{X}_{1}\right)^{2}\right)}}
$$

\section{HASIL DAN PEMBAHASAN}

\section{Kondisi Eksisting Model Pemasaran Produk Masyarakat} Kecamatan Waringin Kurung Kebanyakan desa di Kecamatan Waringin Kurung berfungsi sebagai desa agraris, namun meskipun demikian, beberapa desa sudah menunjukkan perkembangan baru, yaitu munculnya industri-industri kecil yang disebut industri perdesaan (rural industries). Namun laku atau tidaknya hasil industri di desa tersebut ditentukan oleh usaha penduduk desa itu sendiri, desa yang memiliki banyak sumber daya alam tetapi penduduknya tidak cukup mempunyai keterampilan, pengetahuan, dan semangat membangun mengakibatkan desa kurang maju. Sebaliknya, meskipun desa memiliki sumber daya alam terbatas tetapi penduduknya terampil, berpengetahuan, dan bersemangat dalam membangun desa sehingga mampu 
mengatasi hambatan di wilayah maka desa akan cepat maju.

Di Kecamatan Waringin Kurung pada umumnya desa yang terletak di perbatasan kota mempunyai kemungkinan lebih berkembang dibandingkan desa-desa di pedalaman, hal ini disebabkan dengan infrastruktur yang belum merata, sehingga dengan keterbatasan infrastrukur itulah pada umumnya para pelaku usaha yang tinggal di desa atau pedalaman, memiliki model pemasaran hasil produksinya bersifat konvensional atau pemasaran dilakukan hanya untuk memenuhi kebutuhan masyarakat sekitarnya saja, berdasarkan data menggunakan model survey dan wawancara bahwa para pengusaha desa di Kabupaten Serang terutama para pengeola usaha di Kecamatan Waringin Kurung memasarkan produknya dengan cara:

1. Menunggu Konsumen

Pengelola usaha akan memproduksi dengan skala besar dan memasarkannya langsung kepada orang atau tamu yang berkunjung di desanya biasanya ketika di desanya ada acara yang sifatnya seremonial atau ketika ada kunjungan dari aparat pemerintah, atau dewan

2. Personal Seling (door to door)

Pengelola mempekerjakan beberapa orang setempat untuk di jadikan tenaga pemasaran yang tugasnya menawarkan produknya dan menjualnya secara berurutan dari rumah kerumah masyarakat yang ada disekitarnya

3. Pameran Produk Desa

Model pemasaran ini biasanya diselengarakan oleh pemerintah, dan pengelola mendapatkan undangan untuk menempati salah satu stand di acara pameran tersebut, kemudian pengelola produk desa memenuhinya sehingga pengelola dapat menampilkan hasil produksinya atau menjual hasil produksinya

Bagi masyarakat desa keterbatasan pengetahuan dan ketidak jelian pasar justru dimanfaatkan oleh pelaku-pelaku bisnis di daerah (yang dikenal dengan mafia pemasaran). Pelaku ini sering memamfaatkan kondisi di pedesaan untuk mempermainkan harga, sehingga pihak pelaku usaha selalu berada pada posisi tawar menawar yang rendah. Bahkan dalam kondisi tertentu harga hanya ditentukan sepihak oleh para mafia pasar akibatnya pengelola usaha sebenarnya menghadapi pasar monopsonistic.

Berdasarkan survey pendahuluan dapat diinformasikan volume penjualan dari beberapa pengelola produk masyarakat desa di Kecamatan Waringin Kurung dalam penelitian ini:

Tabel 1

Volume penjualan sebelum penerapan pamflet 


\begin{tabular}{|c|c|c|c|c|c|c|}
\hline \multirow{2}{*}{$\begin{array}{l}\mathbf{N} \\
\mathbf{o}\end{array}$} & \multirow{2}{*}{$\begin{array}{c}\text { Nama } \\
\text { Pengel } \\
\text { ola }\end{array}$} & \multirow{2}{*}{$\begin{array}{l}\text { Jenis } \\
\text { Produk }\end{array}$} & \multirow[b]{2}{*}{$\begin{array}{l}\text { Sat } \\
\text { uan }\end{array}$} & \multicolumn{2}{|c|}{$\begin{array}{l}\text { Volume } \\
\text { Penjualan }\end{array}$} & \multirow{2}{*}{$\begin{array}{c}\text { Rerat } \\
\text { a } \\
\text { Penju } \\
\text { alan }\end{array}$} \\
\hline & & & & $\begin{array}{c}\text { Mar } \\
t\end{array}$ & $\underset{\text { Apri }}{\text { Apri }}$ & \\
\hline 1 & Solihin & $\begin{array}{c}\text { Emping } \\
\text { Binangu } \\
\mathrm{n}\end{array}$ & Bks & 122 & 127 & 125 \\
\hline 2 & $\underset{t}{R a h m a}$ & $\begin{array}{c}\text { Emping } \\
\text { Sambila } \\
\text { wang }\end{array}$ & Bks & 154 & 197 & 176 \\
\hline 3 & $\begin{array}{l}\text { M.Han } \\
\text { afi }\end{array}$ & $\begin{array}{c}\text { Anyama } \\
\text { n Hias }\end{array}$ & Pcs & 2 & 2 & 2 \\
\hline 4 & $\begin{array}{c}\text { Hj.Das } \\
\text { inah }\end{array}$ & Ceplis & $\mathrm{Kg}$ & 20 & 30 & 25 \\
\hline 5 & $\begin{array}{c}\text { Siti } \\
\text { Fatona } \\
\text { h }\end{array}$ & $\begin{array}{l}\text { Tahu } \\
\text { Melet }\end{array}$ & Bks & 140 & 170 & 155 \\
\hline 6 & Salkah & $\begin{array}{c}\text { Emping } \\
\text { Sukadal } \\
\text { em }\end{array}$ & $\mathrm{Kg}$ & 140 & 135 & 138 \\
\hline 7 & $\begin{array}{c}\text { Komar } \\
\text { iah }\end{array}$ & Pindang & $\mathrm{Kg}$ & 15 & 20 & 18 \\
\hline
\end{tabular}

Penerapan komunikasi pemasaran model pamflet dalam meningkatkan volume penjualan produk masyarakat desa di Kecamatan Waringin Kurung

Untuk mengatasi masalah pemasaran produk desa yang dialami oleh pengelola usaha produk desa maka perlu dipikirkan paradigma baru dalam mengatasi masalah tersebut. Terutama yang terkait dengan pemasaran produknya. Salah satu alternatif pemecahannya adalah dengan megedukasi masyarakt pada inovasi peningkatan sistem pemasaran produk desanya dan para pengelola usaha produk desa harus bersatu dalam satu wadah kepentingan bersama dalam bentuk model komunikasi pemasaran.

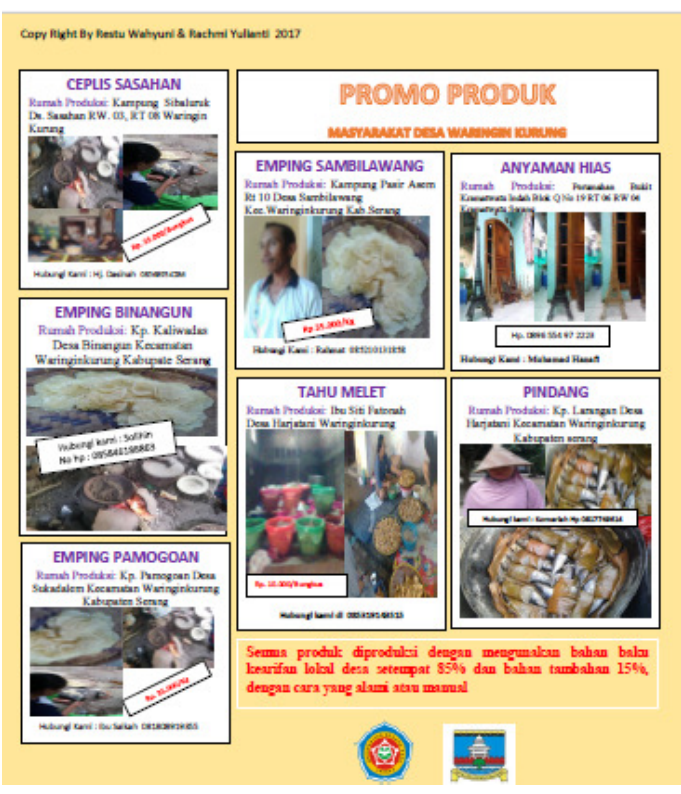

Gambar 1

Perancangan Pemasaran Model Pamflet

Gambar tersebut menggambarkan berbagai produk masyarakat desa di Kecamatan Waringin Kurung yang memuat karakteristik dari pada produk yang akan dipasarkan

\section{Uji Coba Terbatas Penerapan Sistem} Pemasaran Produk Masyarakat Desa

Hasil Pengamatan Perkembangan penjualan Produk Masyarakat Desa di Kecamatan Waringin Kurung setelah diterapkannya komunikasi pemasaran dengan model pamflet: 
Tabel 2

Volume penjualan setelah penerapan pamflet

\begin{tabular}{|c|c|c|c|c|c|c|}
\hline \multirow{2}{*}{$\begin{array}{l}\mathbf{N} \\
\mathbf{0}\end{array}$} & \multirow{2}{*}{$\begin{array}{l}\text { Nama } \\
\text { Penge } \\
\text { lola }\end{array}$} & \multirow{2}{*}{$\begin{array}{l}\text { Jenis } \\
\text { Produ } \\
\text { k }\end{array}$} & \multirow[b]{2}{*}{$\begin{array}{l}\text { Sat } \\
\text { uan }\end{array}$} & \multicolumn{2}{|c|}{$\begin{array}{l}\text { Volume } \\
\text { Penjualan }\end{array}$} & \multirow{2}{*}{$\begin{array}{l}\text { Rerat } \\
\text { a } \\
\text { Penj } \\
\text { ualan }\end{array}$} \\
\hline & & & & Mei & Juni & \\
\hline 1 & $\begin{array}{l}\text { Solihi } \\
\mathrm{n}\end{array}$ & $\begin{array}{l}\text { Empin } \\
\mathrm{g} \\
\text { Binang } \\
\text { un }\end{array}$ & $\begin{array}{l}\text { Bgk } \\
\text { us }\end{array}$ & 140 & 150 & 145 \\
\hline 2 & $\begin{array}{l}\text { Rahm } \\
\text { at }\end{array}$ & $\begin{array}{l}\text { Empin } \\
\text { g } \\
\text { Sambil } \\
\text { awang }\end{array}$ & $\begin{array}{l}\text { Bgk } \\
\text { us }\end{array}$ & 175 & 200 & 188 \\
\hline 3 & $\begin{array}{l}\text { M.Ha } \\
\text { nafi }\end{array}$ & $\begin{array}{l}\text { Anyam } \\
\text { an Hias }\end{array}$ & Pcs & 2 & 3 & 3 \\
\hline 4 & $\begin{array}{l}\text { Hj.Da } \\
\text { sinah }\end{array}$ & Ceplis & $\mathrm{Kg}$ & 50 & 70 & 60 \\
\hline 5 & $\begin{array}{l}\text { Siti } \\
\text { Faton } \\
\text { ah }\end{array}$ & $\begin{array}{l}\text { Tahu } \\
\text { Melet }\end{array}$ & $\begin{array}{l}\text { Bgk } \\
\text { us }\end{array}$ & 170 & 180 & 175 \\
\hline 6 & $\begin{array}{l}\text { Salka } \\
\mathrm{h}\end{array}$ & $\begin{array}{l}\text { Empin } \\
\mathrm{g} \\
\text { Sukada } \\
\text { lem }\end{array}$ & $\mathrm{Kg}$ & 140 & 150 & 145 \\
\hline 7 & $\begin{array}{l}\text { Koma } \\
\text { riah }\end{array}$ & $\begin{array}{l}\text { Pindan } \\
\mathrm{g}\end{array}$ & $\mathrm{Kg}$ & 25 & 30 & 28 \\
\hline
\end{tabular}

\section{Analisis Efektifitas Komunikasi \\ Pemasaran Produk Masyarakat Desa dengan Model Pamflet}

Untuk mengetahui apakah Komunikasi pemasaran dengan model pamflet yang telah di terapkan di Kecamatan Waringin Kurung efektif atau tidak, maka dilakukan pengujian penelitian komparatif pre test dan post test atau penelitian sebelum dan setelah penerapan model itu diterapkan, berikut adalah hasil penghitungan analisis komparatif dengan data periode 2 bulan sebelum penerapan komunikasi pemasaran dengan model pamflet setelah di terapkan

Tabel 3

Data analisis komparatif

\begin{tabular}{|c|c|c|c|c|}
\hline \multirow{2}{*}{$\mathbf{N}$} & \multirow{2}{*}{$\begin{array}{l}\text { Nama } \\
\text { Responden }\end{array}$} & \multirow{2}{*}{ Jenis Usaha } & \multicolumn{2}{|c|}{$\begin{array}{l}\text { Volume } \\
\text { Penjualan } \\
\text { Rata-Rata }\end{array}$} \\
\hline & & & \begin{tabular}{l|} 
Sbl \\
Model
\end{tabular} & $\begin{array}{l}\text { Stlh } \\
\text { Model } \\
\end{array}$ \\
\hline 1 & Solihin & $\begin{array}{l}\text { Emping } \\
\text { Binangun }\end{array}$ & 125 & 145 \\
\hline 2 & Rahmat & $\begin{array}{l}\text { Emping } \\
\text { Sambilawang }\end{array}$ & 176 & 188 \\
\hline 3 & M.Hanafi & Anyaman Hias & 2 & 3 \\
\hline 4 & Hj.Dasinah & Ceplis & 25 & 60 \\
\hline 5 & $\begin{array}{l}\text { Siti } \\
\text { Fatonah }\end{array}$ & Tahu Melet & 155 & 175 \\
\hline 6 & Salkah & $\begin{array}{l}\text { Emping } \\
\text { Sukadalem }\end{array}$ & 138 & 145 \\
\hline 7 & Komariah & Pindang & 18 & 28 \\
\hline & & $\begin{array}{l}\text { Rata-rata sampel } \\
\text { simpangan baku } \\
\text { varian sampel }\end{array}$ & $\begin{array}{r}91 \\
104 \\
10.876\end{array}$ & $\begin{array}{r}106,29 \\
115,19 \\
13.269\end{array}$ \\
\hline
\end{tabular}

Maka berdasarkan nilai-nilai di atas kemudian dengan mengunakan rumusan t-test selanjutnya menguji hipotesis komparatif dua sampel yang berkorelasi dengan nilai korelasi antar dua sampelsebesar $0,99 \quad$ yang dianalisis dengan mengunakan program SPSS versi 21 adalah sebagai berikut : 
Tabel 4

Out put SPSS Correlations

\begin{tabular}{|c|c|c|c|}
\hline & & $\begin{array}{l}\text { Penjualan_- } \\
\text { Sebelum_Sys }\end{array}$ & $\begin{array}{l}\text { Penjualan_ } \\
\text { Setelah_Sys }\end{array}$ \\
\hline \multirow{4}{*}{$\begin{array}{l}\text { Penjualan_ } \\
\text { Sebelum_Sys }\end{array}$} & Pearson Correlation & 1 & .991" \\
\hline & Sig. (2-tailed) & & .000 \\
\hline & $\mathrm{N}$ & 7 & 7 \\
\hline & Pearson Correlation & $.991^{*}$ & 1 \\
\hline \multirow{2}{*}{$\begin{array}{l}\text { Penjualan_ } \\
\text { Setelah_Sys }\end{array}$} & Sig. (2-tailed) & .000 & \\
\hline & $\mathrm{N}$ & 7 & 7 \\
\hline
\end{tabular}

Maka pengujian atas hipotesis komparatif adalah

$$
\begin{aligned}
& \sqrt{\frac{\overline{\mathrm{X}}_{1}-\overline{\mathrm{X}}_{2}}{\frac{\mathrm{s}_{1}^{2}}{\mathrm{n}_{1}+\frac{\mathrm{s}_{2}^{2}}{\mathrm{n}_{2}}-2 \mathrm{r}\left(\frac{\mathrm{s}_{1}}{\sqrt{\mathrm{n}_{1}}}\right)\left(\frac{\mathrm{s}_{1}}{/ \mathrm{n}_{2}}\right)}}} \\
& \mathrm{t}=\sqrt{\frac{91.29-106.29}{\sqrt{10.876,38}+13.269,40}} \\
& \mathbf{t}=\sqrt{\frac{-15}{3.449,39-1.98(39,50)(43,63)}} \\
& \mathrm{t}=\sqrt{\frac{-15}{3.449,39-1.98(1.723,385)}} \\
& -15 \\
& \mathrm{t}=\sqrt{\overline{3.449,39-3.412,30}} \\
& \mathrm{t}=\frac{-15}{6,09} \quad=\mathbf{2 , 4 6 3}
\end{aligned}
$$

Dan dari penghitungan uji hipotesis tersebut dihasilkan nilai $\mathrm{t}$ hitung sebesar 2,463 yang selanjutnya nilai tersebut dibandingkan dengan nilai $\mathrm{t}$ tabelnya dengan $\mathrm{dk}=\mathrm{n}_{1}+\mathrm{n}_{2} 7+7=14-2=12$. dengan derajat kebebasan $(\mathrm{dk})=12$ dan taraf kesalahan ditetapkan sebesar 5\%, maka nilai t tabel yang di hasilkan adalah 1,782 Sehingga dengan kriteria Uji yang telah ditentukan adalah sebagai berikut

- Jika t hitung lebih besar dari pada $\mathrm{t}$ tabel (thitung $>\mathrm{t}$ table) maka Ho ditolak sedangkan ha diterima (Komunikasi Pemasaran dengan model pamflet efektif)

- Jika t hitung lebih kecil dari t table (thitung $<\mathrm{t}$ table) maka Ho diterima sedangkan ha ditolak (komunikasi pemasaran dengan model pamflet tidak efektif)

Maka sesuai dengan kriteria uji tersebut hasil penelitian ini adalah $\mathrm{t}$ hitung lebih kecil dari $\mathrm{t}$ tabel $(-2.463<-1,782)$ sehingga Ho ditolak dan Ha diterima, ini maknanya adalah terdapat perbedaan secara signifikan efektifitas kinerja komunikasi Pemasaran masyarakat desa di Kecamatan Waringin Kurung sebelum dan setelah penerapan model pamflet.

\section{SIMPULAN}

Selanjutnya, berdasarkan hasil analisis dan pengujian hipotesis dapat disimpulkan sebagai berikut:

- Masih banyak sumber daya yang dimiliki oleh masyarakat desa yang jika di kelola dengan baik maka, akan menghasilkan berbagai macam produk inovatif dan menjadi unggulan, namun 
berdasarkan survey masyarakat masih banyak yang memilih bekerja pabrik di kota

- Karena terkendala infrastruktur, tingkat pendidikan model pemasaran produk pengelolaan dan industri desa masih sangat konvensional seperti model pemasaran menunggu konsumen datang berkunjung ke desanya, menjajakan hasil produknya dengan cara menawarkan dari rumah ke rumah (door to door) dan pameran produk desa yang diselenggarakan oleh pemerintah

- Bagi masyarakat desa keterbatasan pengetahuan dan ketidakjelian pasar justru dimanfaatkan oleh pelaku-pelaku bisnis di daerah (yang dikenal dengan mafia pemasaran). Pelaku ini sering memanfaatkan kondisi di pedesaan untuk mempermainkan harga, sehingga pihak pelaku usaha selalu berada pada posisi tawar menawar yang rendah.

- Hasil penghitungan uji hipotesis menyimpulkan bahwa terdapat perbedaan secara signifikan efektifitas kinerja komunikasi pemasaran masyarakat desa di Kecamatan Waringin Kurung sebelum dan setelah penerapan model pamflet

\section{DAFTAR PUSTAKA}

Fandy Tjiptono, 2012, Strategi Pemasaran. Edisi ke dua, penerbit Andi, Yogyakarta.

Kotler Philip alih bahasa Drs. Benyamin Molan ,2011, Manajemen Pemasaran jilid 1, Jakarta, penerbit PT Indeks Kelompok Gramedia.

Komaruddin Sastra Dipoera. 2006. Manajemen Marketing. Penerbit Kapa Sigma, Bandung.

Moekijat, 2000. Kamus Manajemen. Bandung : Penerbit CV. Mandar Maju.

Sutisna. 2011. Perilaku Konsumen dan Komunikasi Pemasaran. Bandung: PT Remaja Rosdakarya

Sugiyono. 2012. Metode Penelitian Bisnis (cetakan ke-lima). Bandung : CV Alfabeta

Sciffman Leon G dan kanuk, 2010 Customer Behavior Tenth edition, Person Education 
